SECRETory leukocyte protease inhibitor (SLPI) is a wellknown protease inhibitor. Its function is thought to be protease/protease-inhibitor balance. Free proteolytic activity, mainly pancreatic elastase, anionic trypsin and granulocytic elastase, has been demonstrated in faecal extracts from patients with ulcerative colitis. We wanted to verify that SLPI is actually secreted from normal human colonic mucosa. Also, we wanted to ascertain whether studies of SLPI secretion based on punch biopsies were dependent on biopsy area or on biopsy circumference. Normal colonic mucosa was sampled during surgery for colonic cancer. A total of 36 samples from four patients were used. Mucosa preparation was carried out using a punch biopsy technique, and samples of 3 , 4 and $6 \mathrm{~mm}$ diameter were used. All media contained SLPI at varying concentrations. When expressed in terms of the sample area, the secretion per millimetre-squared seemed to decrease with increasing area. When calculated as secretion per circumference, secretion seemed to be constant. In conclusion, SLPI was secreted from normal human colonic mucosa. The SLPI secretion seemed dependent on the circumference of the biopsy rather than on the area of the biopsy.

Key words: Trauma, Human cell culture, Punch biopsy, Anti-leukoprotease

\section{Secretory leukocyte protease inhibitor in punch biopsies from human colonic mucosa}

\author{
Max Nyström ${ }^{1,2, C A}$, Ulla Peterson Westin ${ }^{2}$, \\ Carina Linder ${ }^{2}$ and Kjell Ohlsson ${ }^{2}$
}

${ }^{1}$ Department of Surgery and ${ }^{2}$ Department of Surgical Pathophysiology, Ing 37, Lund University, University Hospital Malmö, SE 20502 Malmö, Sweden

${ }^{\mathrm{CA}}$ Corresponding Author
Tel: +4640333150
Fax: +4640336240
E-mail: max.nystrom@swipnet.se

\section{Introduction}

Secretory leukocyte protease inhibitor (SLPI) is a $12 \mathrm{kDa}$ non-glycosylated acid-stable antiprotease. Its amino acid sequence was elucidated in $1986 .^{1}$ Its inhibitory activity against leukocytic as well as pancreatic elastase, cathepsin G, trypsin and chymotrypsin is well known. ${ }^{1-4}$ It was first found in cervical secretions ${ }^{5}$ and has since been found on a variety of different cell surfaces. It appears in large quantities in parotid secretions ${ }^{6}$ as well as in bronchial secretions. $^{7,8}$ Its role is thought to be mainly the modulation of the inflammatory process. In addition, both antibacterial and antiviral properties have been reported. ${ }^{9-12}$ Increased concentrations have been reported in pneumonia among the elderly. ${ }^{13}$

Large amounts of SLPI are swallowed ${ }^{3,14,15}$ and are rapidly degraded in gastric and duodenal juices. ${ }^{16}$ Recently, SLPI was demonstrated in the intestinal mucosa. ${ }^{17}$ Large amounts of free proteolytic activity, mainly pancreatic elastase and trypsin, have been found in secretions from patients with ulcerative colitis. ${ }^{18,19}$ SLPI secretion and regulation in response to these and other agents is thus of considerable interest. In this study, we wanted to verify that human colonic mucosa was capable of SLPI secre- tion. For future studies, we also wanted to ascertain whether studies of SLPI based on punch biopsies were mainly dependent on biopsy area or on biopsy circumference.

\section{Materials and methods}

\section{Mucosal culture}

The procedure was approved by the local ethical committee and was performed in accordance with the Helsinki declaration. Tissue from macroscopically normal colonic mucosa was taken during surgery for the removal of colonic carcinoma from four patients with no other known bowel disease. The mean age of the patients was 64 years. The mucosa was sampled as $2-3 \mathrm{~cm}$ of tissue from the end of the excised material, at the end opposite to the cancer. It was placed in transport medium immediately after the blood supply was cut off, and then washed in separate test tubes containing transport medium three times, each washing lasting $2 \mathrm{~min}$. All media were obtained from Gibco, Life Technologies AB (Sweden).

The transport medium consisted of $500 \mathrm{ml}$ of Minimum Essential Medium (MEM) with Earle's Salts, with L-glutamine (catalogue number 31095-086), 
$5 \mathrm{ml}$ of $0.1 \mathrm{mM}$ MEM non-essential amino acids (catalogue number 11140-35), $10 \mathrm{ml}$ of sodium pyruvate (catalogue number 11360-039), $5 \mathrm{ml}$ of PEST (catalogue number 15140-114), and $0.5 \mathrm{ml}$ of gentamycin sulphate (catalogue number 5750-037). The culture medium was the same but $10 \%$ foetal calf serum was added. In the laboratory, the mucosa was carefully dissected with scissors and samples punched out with a KAI sterile disposable biopsy punch (Stille, Sweden). Nine punch biopsies were taken from each of the patients. Biopsy diameters of 3,4 and $6 \mathrm{~mm}$ were used. Three biopsies of each size were taken. A total of 36 biopsies were thus collected. After punching, the biopsies were immediately placed on the grid of a $10 \mathrm{~mm}$ diameter Falcon cell culture insert, with $3.0 \mu \mathrm{m}$ of HD (high pore density membrane), and then placed in the 12-well companion plate for tissue culture (Labora, Sweden). The total well volume was $3 \mathrm{ml}$. The biopsies were incubated for $24 \mathrm{~h}$ in a Modular Incubator Chamber (Billrups, Rothenberg, CA, USA) at $37.4^{\circ} \mathrm{C}$. The Modular Incubator Chamber was preventilated for $10 \mathrm{~min}$ with $95 \% \mathrm{O}_{2}+5 \% \mathrm{CO}_{2}$. The mucosa samples were then removed, and the medium was collected and then centrifuged at $4000 \mathrm{rpm}$ for $10 \mathrm{~min}$ at $+4^{\circ} \mathrm{C}$. The supernatant was carefully collected and stored in aliquots at $-70^{\circ} \mathrm{C}$ until analysed for the presence of SLPI by a standard enzyme-linked immunosorbent assay (ELISA) kit obtained from RD Systems (Quantikine human SLPI immunoassay). All analyses were performed in duplicate and the average was used in all calculations.
Table 1. Mean concentration of SLPI in growth medium (ng/l) after $24 \mathrm{~h}$ according to patient and the biopsy diameter

\begin{tabular}{lrrr}
\hline Patient & $\begin{array}{c}3 \mathrm{~mm} \\
\text { diameter }\end{array}$ & $\begin{array}{c}4 \mathrm{~mm} \\
\text { diameter }\end{array}$ & $\begin{array}{c}6 \mathrm{~mm} \\
\text { diameter }\end{array}$ \\
\hline 1 & 435.9 & 540.0 & 1073.8 \\
2 & 429.1 & 324.9 & 541.7 \\
3 & 1354.4 & 1575.6 & 2200.6 \\
4 & 1466.3 & 2082.3 & 3113.3 \\
\hline
\end{tabular}

Detailed information about specificity, accuracy and precision is given in the ELISA manual. According to this, the minimal detectable dose is typically less than $25 \mathrm{ng} / \mathrm{l}$. At mean concentrations of 109, 696 and $2026 \mathrm{ng} / 1$, the standard deviation is $8.7,37.1$ and 84.1 , respectively. The analysis of variance factorial was used for statistical analysis.

\section{Results}

All media contained SLPI at varying concentrations ranging from 199 to $3258 \mathrm{ng} / \mathrm{l}$. Media concentrations are presented in Table 1.

\section{Secretion of SLPI expressed as nanograms per litre per unit area $\left(\mathrm{mm}^{2}\right)$}

The mean calculated secretion per unit area was $130.4 \mathrm{ng} / 1$ per $\mathrm{mm}^{2}$ in the $3 \mathrm{~mm}$ diameter samples (range, $29.3-266.1 \mathrm{ng} / \mathrm{l}$ ), in the $4 \mathrm{~mm}$ diameter sam-

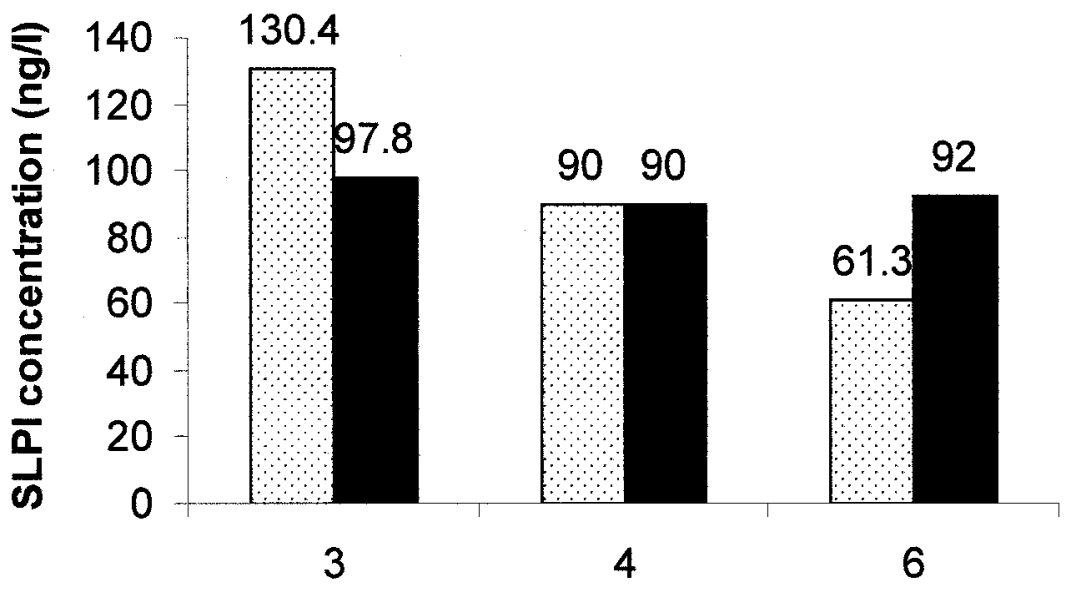

Biopsy diameter (mm)

\section{SLPI concentration/area $\square$ SLPI concentration/circumference}

FIG. 1. SLPI calculated as mean concentration per area (light shading). In the $3 \mathrm{~mm}$ diameter samples the mean concentration was $130.4 \mathrm{ng} / \mathrm{l}$ per $\mathrm{mm}^{2}(\mathrm{SD}=83.4)$, in the $4 \mathrm{~mm}$ samples it was $90 \mathrm{ng} / \mathrm{l} \mathrm{per} \mathrm{mm}^{2}(\mathrm{SD}=62.6)$, and in the $6 \mathrm{~mm}$ diameter samples it was $61.3 \mathrm{ng} / \mathrm{l}$ per $\mathrm{mm}^{2}(\mathrm{SD}=38.3)$. When calculated as mean concentration per circumference (dark shading), the concentration in the $3 \mathrm{~mm}$ diameter samples was $97.8 \mathrm{ng} / \mathrm{l}$ per $\mathrm{mm}(\mathrm{SD}=62.6)$, in the $4 \mathrm{~mm}$ samples it was $90 \mathrm{ng} / \mathrm{l} \mathrm{per} \mathrm{mm} \mathrm{(SD}$ $=92.6)$, and in the $6 \mathrm{~mm}$ diameter sample group it was $92 \mathrm{ng} / \mathrm{l}$ per $\mathrm{mm}(\mathrm{SD}=57.5)$. There was no significant difference in SLPI concentration between sample groups when calculated as concentration per circumference. SLPI secretion decreased with increasing sample area. 
ples the mean secretion was $90.0 \mathrm{ng} / \mathrm{l}$ per $\mathrm{mm}^{2}$ (range, $15.8-200.9 \mathrm{ng} / \mathrm{l}$ ), and in the $6 \mathrm{~mm}$ diameter samples it was $61.3 \mathrm{ng} / 1$ per $\mathrm{mm}^{2}$ (range, 12.3-115.3 ng/1). There was no significant difference in the secretion per $\mathrm{mm}^{2}$ between the $3 \mathrm{~mm}$ diameter samples and the $4 \mathrm{~mm}$ diameter samples $(p>0.13)$. No significant difference in secretion per $\mathrm{mm}^{2}$ was shown between the $4 \mathrm{~mm}$ diameter samples and the $6 \mathrm{~mm}$ diameter samples $(p>0.28)$. There was, however, a significant difference in the secretion between the $3 \mathrm{~mm}$ diameter samples and the $6 \mathrm{~mm}$ samples $(\phi=0.0126)$, The secretion seemed to decrease with increasing area (see Fig. 1).

\section{Secretion of SLPI expressed as nanograms per litre per circumference of the sample $(\mathrm{mm})$}

The calculated secretion per litre per circumference in the $3 \mathrm{~mm}$ diameter samples was $97.8 \mathrm{ng}$ (range, 22.0-199.6 ng), in the $4 \mathrm{~mm}$ diameter samples the secretion was $90.6 \mathrm{ng}$ (range, 24.7-200.9 ng), and in the $6 \mathrm{~mm}$ diameter samples it was $92.0 \mathrm{ng}$ (range, 24.9-172.9 ng). There was no significant difference in secretion calculated as secretion per circumference between any of the sample groups $(p>$ 0.47) (see Fig. 1).

\section{Discussion}

SLPI is a protease secreted by a variety of mucosal cells. Interest in the phenomenon has mainly been directed towards the upper respiratory tract. Its role is thought to be mainly downregulation of the inflammatory process. The production of SLPI has also been demonstrated in the large and small intestines. $^{17}$ In this study, we verified that SLPI is also found in the medium from cultured normal human colonic mucosa. The SLPI concentration after $24 \mathrm{~h}$ of incubation ranged from 199 to $3258 \mathrm{ng} / 1$. Interpersonal differences in initial SLPI cell content might be an explanation for variation between patients with the same biopsy size. During surgery, the tissue is subject to considerable trauma, both direct cell trauma and indirect trauma, e.g. due to decreased blood supply. Further trauma is induced during punching as direct cell trauma. Wounded cells might also interact with cells in their close vicinity. When expressing the total cell production of SLPI in terms of the sample area, there was a significant difference in secretion between the $3 \mathrm{~mm}$ samples and the $6 \mathrm{~mm}$ samples. The secretion per $\mathrm{mm}^{2}$ seemed to decrease with increasing area. This might possibly be explained by decreased metabolism in the centre of the biopsies where cells are mainly in contact with the medium from above and below. Cells located on the borders of the biopsies are in contact with the medium also on almost all sides, which could lead to a somewhat higher metabolism. Another plausible explanation might be secretion from cells caused directly or indirectly by the punching procedure. In either case, expressing the secretion as a function of the biopsy circumference would be a possible way to determine whether the cells located on the border were the most active secreting cells in the biopsies.

No significant difference was observed between any of the samples when secretion was expressed as secretion per circumference. In this study, the secretion therefore seemed to be influenced mainly by the circumference of the biopsies (Fig. 1). This could be explained both by decreased metabolism in the middle of the biopsy as well as direct physical injury caused by the punching procedure. We hence conclude that SLPI is not only produced in normal human colonic mucosa as indicated by earlier studies, but is also actually secreted. In this study, secretion seems to take place mainly from cells located on the edges of the biopsies rather than from all the cells cultured.

ACKNOWLEDGEMENTS. This project was supported by the Swedish Society of Medicine, the Medical Faculty at Lund University, the Swedish Medical Research Council (03910), the Foundation for Surgical Research, and the Department for Surgery, University Hospital Malmö.

\section{References}

1. Thompson RC, Ohlsson $\mathrm{K}$. Isolation, properties, and complete amino acid sequence of human secretory leukocyte protease inhibitor, a potent inhibitor of leukocyte elastase. Proc Natl Acad Sci USA 1986; 83: 6692-6696.

2. Håkansson $\mathrm{HO}$, Ohlsson K. Influence of plasma proteinase inhibitors and the secretory leukocyte proteinase inhibitor on pancreatic elastaseinduced degradation of some plasma proteins. Gastroenterol Jpn 1992; 27: 652-656.

3. Ohlsson K, Tegner H. Inhibition of elastase from granulocytes by the low molecular weight bronchial protease inhibitor. Scand J Clin Lab Invest 1976; 36: 437-445.

4. Hochstrasser K, Reichert R, Schwarz S, Werle E. Isolierung und charakterisierung eines proteaseninhibitors aus menschlichem bronchialsekret. Biol Chem Hoppe-Seyler 1972; 353: 221-226.

5. Wallner $\mathrm{O}$, Fritz $\mathrm{H}$. Characterization of an acid stable proteinase inhibitor in human cervical mucus. Hoppe-Seyler's Z Physiol Chem 1974; 355 : $709-715$.

6. Ohlsson K, Rosengren M, Tegner H. Quantification of granulocyte elastase inhibitors in human mixed saliva and in pure parotid secretion. Hoppe-Seyler's Z Physiol Chem 1983; 364: 1323-1328.

7. Tegner H, Ohlsson K, Olsson I. The interactions between a low molecular weight protease inhibitor of bronchial mucus and chymotrypsin-like cationic proteins of granulocytes. Hoppe-Seyler's Z Physiol Chem 1977; 358: 431-433.

8. Mooren HWD, Kramps JA, Franken C, Meijer CJLM, Dijkman JA Localisation of a low-molecular-weight bronchial protease inhibitor in the peripheral human lung. Thorax 1983; 38: 180-183.

9. Masuda K, Kamimura T, Watanabe K, Suga T, Kanesaki M, Takeuchi A, et al. Pharmacological activity of the C-terminal and N-terminal domains of secretory leukoprotease inhibitor in vitro. Br J Pharmacol 1995; 115: 883-888.

10. Hiemstra PS, Maassen RJ, Stolk J, HeinzelWieland R, Steffens GJ, Dijkman $\mathrm{JH}$. Antibacterial activity of antileukoprotease. Infect Immun 1996; 64: 4520-4524.

11. McNeely TB, Dealy M, Dripps DJ, Orenstein JM, Eisenberg SP, Wahl SM. Secretory leukocyte protease inhibitor: a human saliva protein exhibiting anti-human immunodeficiency virus 1 activity in vitro. $J$ Clin Invest 1995; 96: 456-464 
12. McNeely TB, Shugars DC, Rosendahl M, Tucker C, Eisenberg SP, Wahl SM Inhibition of human immunodeficiency virus type 1 infectivity by secretory leukocyte protease inhibitor occurs prior to viral reverse transcription. Blood 1997; 90: 1141-1149.

13. Kida K, Mizuuchi T, Takeyama K, Hiratsuka T, Jinno S, Hosoda K, et al. Serum secretory leukoprotease inhibitor levels to diagnose pneumonia in the elderly. Am Rev Respir Dis 1992; 146: 1426-1429.

14. Lee $\mathrm{CH}$, Igarashi $\mathrm{Y}$, Hohman RJ, Kaulbach $\mathrm{H}$, White MV, Kaliner MA Distribution of secretory leukoprotease inhibitor in the human nasal airway. Am Rev Respir Dis 1993; 147: 710-716.

15. Geigy scientific tables. In: Lentner C ed. Units of Measurement, Body Fluids, Composition of the Body Nutrition; Switzerland: Ciba Geigy 1982:114.

16. Nyström M, Bergenfeldt M, Ohlsson K. The elimination of secretory leukocyte protease inhibitor (SLPI) from the gastrointestinal tract in man. Scand J Clin Lab Invest 1997; 57: 119-126.
17. Bergenfeldt M, Nyström M, Bohe M, Lindstrom C, Polling A, Ohlsson K Localization of immunoreactive secretory leukocyte protease inhibitor (SLPI) in intestinal mucosa. J Gastroenterol 1996; 31: 18-23.

18. Bohe M. Pancreatic and granulocytic endoproteases in faecal extracts from patients with active ulcerative colitis. Scand J Gastroenterol 1987; 22: 59-64.

19. Bohe M, Borgstrom A, Genell S, Ohlsson K. Determination of immunoreactive trypsin, pancreatic elastase and chymotrypsin in extracts of human feces and ileostomy drainage. Digestion 1983; 27: 8-15.

Received 24 June 2001;

Accepted 16 July 2001 


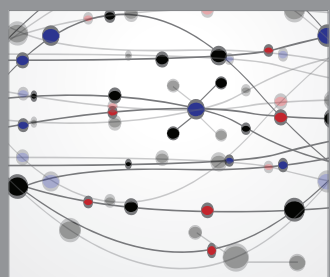

The Scientific World Journal
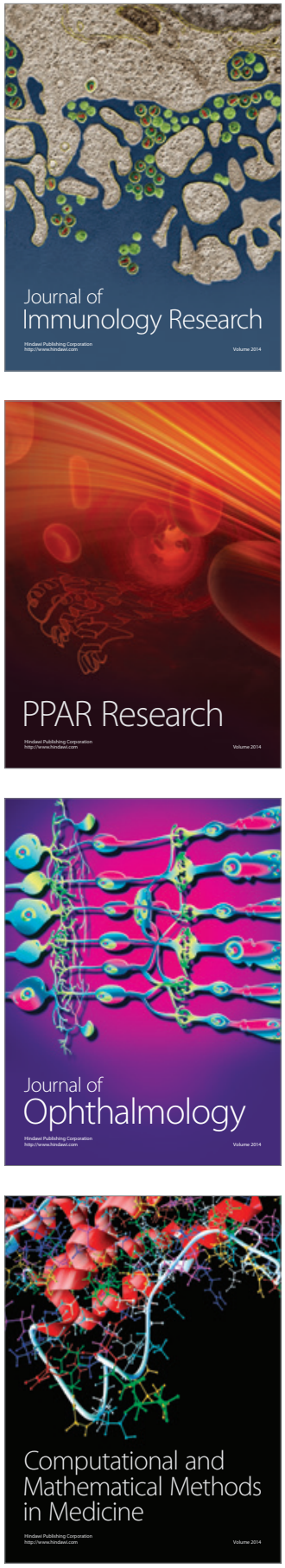

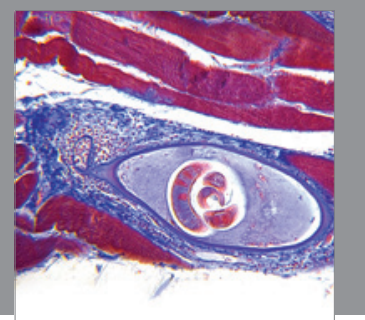

Gastroenterology

Research and Practice
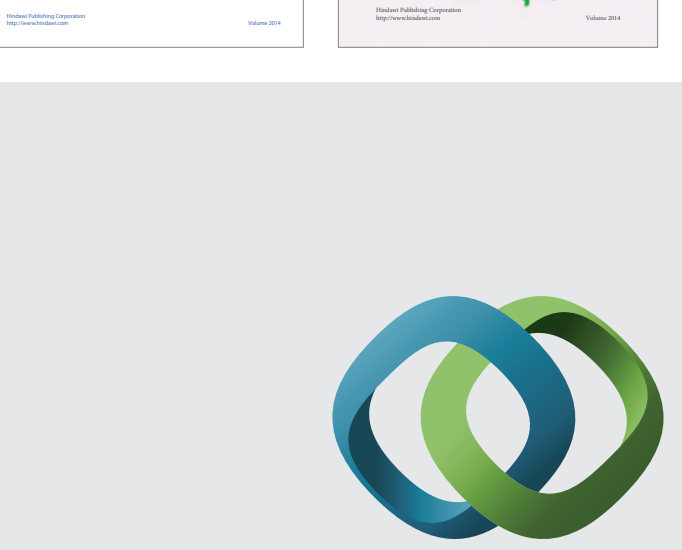

\section{Hindawi}

Submit your manuscripts at

http://www.hindawi.com
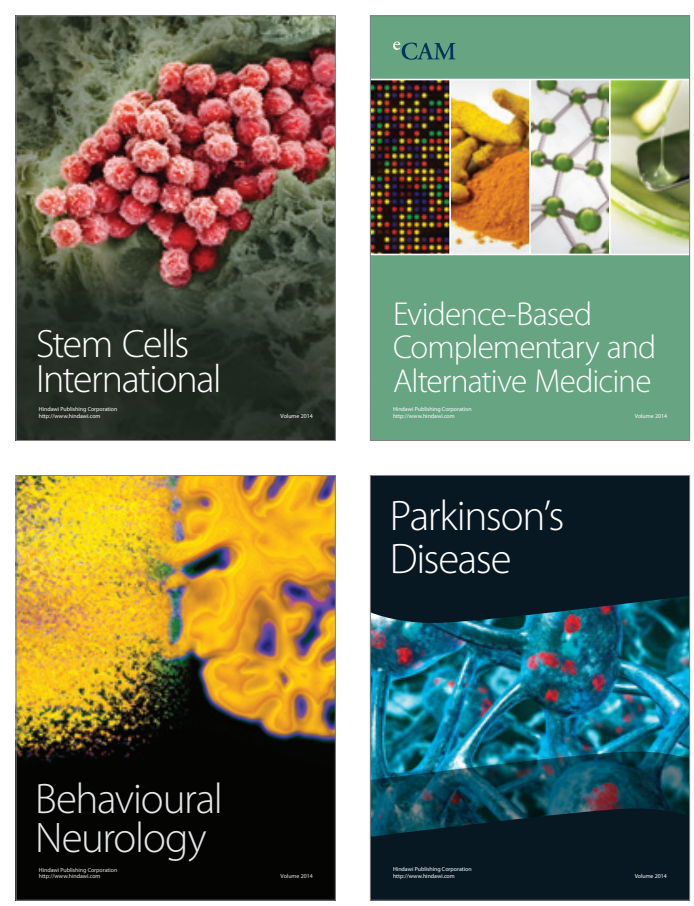

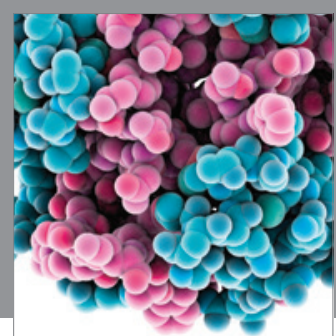

Journal of
Diabetes Research

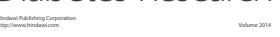

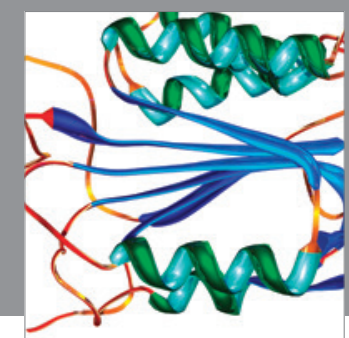

Disease Markers
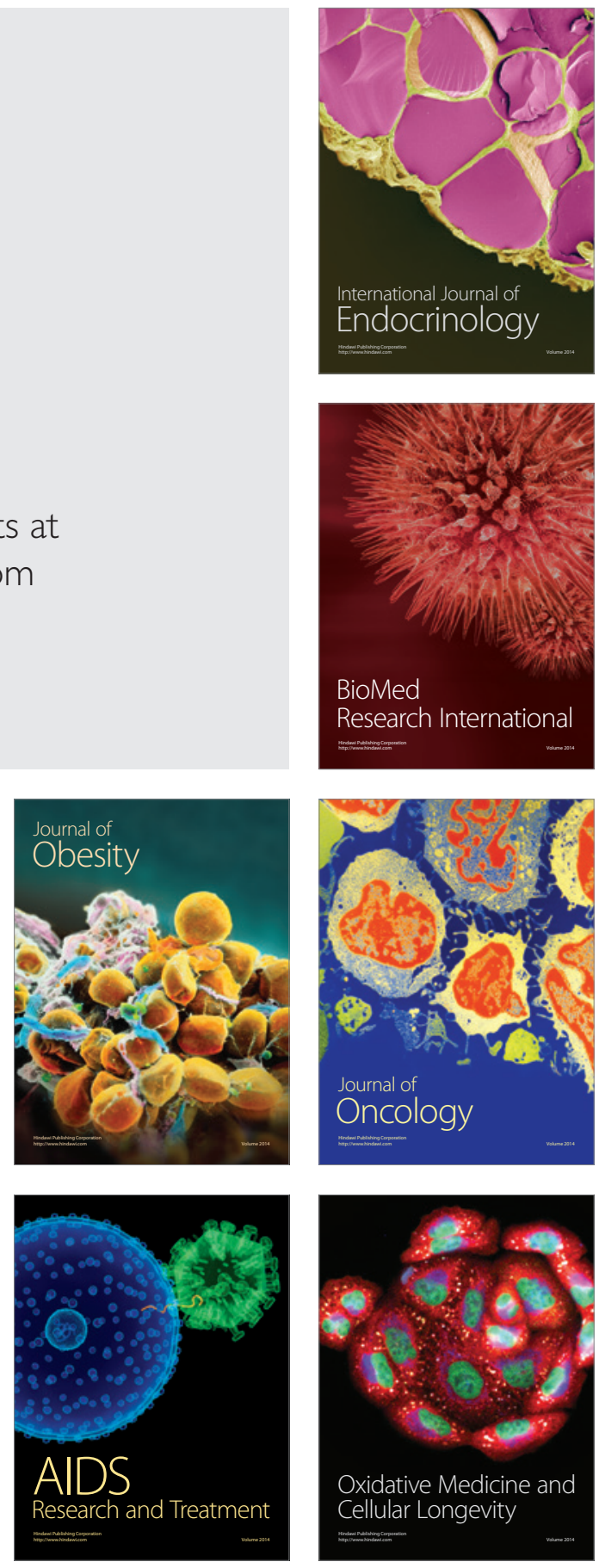